\title{
Perbandingan Kualitas Tidur Mahasiswa Fakultas Kedokteran Universitas Padjadjaran yang Menggunakan dan tidak Menggunakan Cahaya Lampu Saat Tidur
}

\author{
Riska Sutrisno ${ }^{1}$, Faisal $^{2}$, Fathul Huda ${ }^{3}$ \\ ${ }^{1}$ Fakultas Kedokteran, Universitas Padjadjaran \\ ${ }^{2}$ Departemen Ilmu Kesehatan Anak, Fakultas Kedokteran Universitas Padjadjaran/ \\ Rumah Sakit Umum Pusat Dr. Hasan Sadikin, Bandung \\ ${ }^{3}$ Departemen Anatomi, Fisiologi dan Biologi Sel, Fakultas Kedokteran Universitas Padjadjaran/ \\ Rumah Sakit Umum Pusat Dr. Hasan Sadikin, Bandung
}

\begin{abstract}
Abstrak
Irama sirkadian dipengaruhi oleh cahaya lampu dapat menghambat pembentukan hormon melatonin. Baik dan buruknya tidur dilihat dari kualitas tidur. Kualitas tidur buruk memengaruhi keseimbangan fisiologis dan psikologis. Khususnya pada mahasiswa menyebabkan penurunan konsentrasi dan disfungsi aktivitas di siang hari. Penelitian dilakukan pada bulan Juli-November 2016 di Fakultas Kedokteran Universitas Padjadjaran, Jatinangor dan bertujuan untuk mengetahui perbandingan kualitas tidur mahasiswa Fakultas Kedokteran Universitas Padjadjaran yang menggunakan dan tidak menggunakan cahaya lampu saat tidur. Penelitian dengan pendekatan potong lintang ini dilakukan pada populasi yaitu mahasiswa Fakultas Kedokteran Universitas Padjadjaran. Besar sampel berdasarkan rumus analitik komparatif kategorik-kategorik tidak berpasangan sejumlah 80 responden berjenis kelamin laki-laki untuk setiap kategorinya. Instrumen penelitian ini adalah kuesioner Pittsburgh Sleep Quality Index (PSQI) dengan analisis statistik yang digunakan adalah uji Chi-Square. Dari 160 subjek penelitian didapatkan sejumlah 80 orang yang menggunakan lampu dan 80 orang tidak menggunakan lampu saat tidur. Perbandingan kualitas tidur antara kelompok subjek yang menggunakan lampu dan tidak menggunakan lampu dengan uji chi-square didapatkan perbedaan yang tidak bermakna dengan mayoritas subjek memiliki kualitas tidur buruk $(p=0,191)$. Hasil menunjukkan bahwa tidak terdapat perbedaan kualitas tidur mahasiswa Fakultas Kedokteran Universitas Padjadjaran yang menggunakan dan tidak menggunakan cahaya lampu saat tidur.
\end{abstract}

Kata Kunci : Cahaya lampu, Kualitas tidur, Mahasiswa

\section{Sleep Quality Comparison Between Medical Students of Universitas Padjadjaran Who Sleep with and Without Lamp Lights}

\begin{abstract}
Circadian rhythm which works as sleep controller has exogenous factor, i.e. lamp light exposure causing an inhibition in the synthesis of melatonin hormone. Sleep is good or bad could be assessed from sleep quality. Poor sleep quality affects physiologic and psychologic balance. Especially in students, poor sleep quality might cause a decreased concentration and dysfunctional activity during the day. This study was conducted from July-November 2016 in Faculty Medicine of Universitas Padjadjaran, Jatinangor and aims to understand the sleep quality comparison between medical students of Universitas Padjadjaran who sleep with and without lamp lights. This was a cross sectional study conducted on medical students of Universitas Padjadjaran as the study subjects. The sample size was measured using non-paired categorical analytic comparative formula, then obtained 80 male subjects for each category as the result. The instrument used in this study was Pittsburgh Sleep Quality Index (PSQI) questionnaire with statistical analysis done using Chi-square test. Among 160 study subjects, there were 80 subjects who used lamp and another 80 subjects who did not used lamp during sleep. Sleep quality comparison on each subject group with and without lamp light during sleep was measured using chi-square test and the result showed that the two were not statistically significant with most of subjects have poor quality of sleep $(p=0.191)$. This study reveal that there were no difference of sleep quality between medical students of Universitas Padjadjaran who sleept with and without lamp lights.
\end{abstract}

Keywords : Lamp light, Sleep quality, Students

Korespondensi:

Riska Sutrisno

Fakultas Kedokteran Universitas Padjadjaran

Jl. Raya Bandung-Sumedang KM 21 Jatinangor, Sumedang

Mobile : 085794800562

Email : riskasutrisno11@gmail.com 


\section{Pendahuluan}

Tidur didefinisikan sebagai keadaan bawah sadar saat seseorang dapat dibangunkan dengan rangsang sensorik atau ransang lainnya. ${ }^{1}$ Setiap individu memiliki perbedaan waktu istirahat, tidur dan terjaga sesuai dengan tahapan tidur dan aktivitas harian yang dijalani. Waktu tidur dan terbangunnya seseorang diatur oleh irama biologis yaitu irama sirkadian. ${ }^{2,3}$ Irama sirkadian dipengaruhi oleh faktor eksogen berupa paparan cahaya lampu. Cahaya lampu berpengaruh terhadap pembentukan hormon melatonin yang berperan dalam proses tidur-bangunnya seseorang. Terhambatnya pembentukan hormon melatonin dapat memberikan perintah kepada tubuh manusia untuk mengabaikan tidur dan melakukan aktivitas lebih lama di malam hari sehingga, berdampak pada gangguan kebutuhan tidur, perubahan emosi, perilaku dan kesehatan mental. ${ }^{4,5}$ Gangguan kebutuhan tidur ini dapat dilihat dari kualitas tidur. $^{6}$ Kualitas tidur adalah kepuasan seseorang terhadap tidur yang dapat diukur melalui beberapa aspek seperti jumlah waktu tidur, hambatan memulai tidur, waktu terbangun, efisiensi tidur dan keadaan yang mengganggu saat tidur. Tidur yang tidak adekuat dapat menghasilkan kualitas tidur yang buruk. Kualitas tidur yang buruk berdampak pada gangguan keseimbangan fisiologis dan psikologis. ${ }^{7}$

Penelitian yang dilakukan oleh Ryan Cho tahun 2013 menunjukkan hasil bahwa responden yang menggunakan lampu saat tidur mayoritas memiliki tidur yang kurang nyenyak dan menghasilkan kualitas tidur yang buruk. ${ }^{8} \mathrm{Hal}$ ini dikarenakan cahaya lampu merupakan penyelaras utama irama sirkadian yang memiliki pengaruh terhadap kewaspadaan, suhu tubuh dan produksi hormon melatonin. ${ }^{8}$ Kualitas tidur berdasarkan jenis kelamin menunjukkan bahwa perempuan lebih berisiko memiliki kualitas tidur yang buruk dibandingkan dengan laki-laki. ${ }^{9}$ Pernyataan tersebut sesuai dengan penelitian yang dilakukan oleh Akhlaghi dan Ghalebandi di Iran pada tahun 2009 dan didukung juga dengan penelitian yang dilakukan oleh Regal, dkk. yang menjelaskan perempuan lebih cenderung dipengaruhi oleh perubahan hormon yang dapat menyebabkan gangguan pada kualitas tidur. ${ }^{10,11}$

Berdasarkan penelitian yang dilakukan oleh Aabid Ali pada mahasiswa kedokteran di salah satu Universitas di Pakistan menunjukkan hasil bahwa mahasiswa kedokteran memiliki hari dan waktu malam yang lebih berat karena adanya tuntutan untuk mengerjakan tugas presentasi, persiapan ujian mingguan dan bulanan serta kegiatan keorganisasian yang harus diselesaikan dalam waktu terbatas. Hal ini membuat mahasiswa kedokteran lebih berisiko terpapar cahaya lampu lebih lama pada malam hari. Berdasarkan penelitian tersebut menyatakan bahwa mahasiswa kedokteran memiliki kualitas tidur yang buruk sehingga berdampak pada penurunan konsentrasi saat proses belajar dan disfungsi aktivitas di siang hari seperti adanya rasa kantuk yang berlebihan di siang hari. ${ }^{12,13}$ Berdasarkan uraian di atas, peneliti ingin melakukan penelitian pada mahasiswa Fakultas Kedokteran Universitas Padjadjaran berjenis kelamin laki-laki mengenai perbandingan kualitas tidur mahasiswa Fakultas Kedokteran Universitas Padjadjaran yang menggunakan dan yang tidak menggunakan cahaya lampu saat tidur.

\section{Metode}

Penelitian ini bersifat analitik dengan menggunakan pendekatan potong lintang yang dilakukan pada populasi yaitu Mahasiswa Fakultas Kedokteran Universitas Padjadjaran. Penelitian ini dilakukan pada bulan JuliNovember tahun 2016 di Fakultas Kedokteran Universitas Padjadjaran, Jatinangor. Pengambilan sampel dilakukan pada bulan Oktober tahun 2016 beberapa minggu sebelum responden mengikuti ujian tengah semester. Hal ini menjadi pertimbangan peneliti yang bertujuan untuk mengurangi bias berupa stres akademik saat ujian dan sudah mempertimbangkan bahwa satu bulan sebelumnya responden sudah beradaptasi terhadap lingkungannya. Besar sampel yang didapatkan berdasarkan perhitungan analitik komparatif kategorik-kategorik tidak berpasangan adalah responden berjenis kelamin laki-laki sejumlah 80 responden yang menggunakan lampu dan 80 responden yang tidak menggunakan lampu saat tidur.

Sampel diambil dengan teknik konsekutif yaitu setiap subjek yang memenuhi kriteria inklusi dimasukkan kedalam penelitian sampai kurun waktu tertentu, sehingga jumlah subjek penelitian yang diperlukan terpenuhi. Kriteria inklusi pada penelitian ini adalah Mahasiswa Fakultas Kedokteran Universitas Padjadjaran yang terdaftar sebagai angkatan tahun pertama, kedua, ketiga dan keempat berjenis kelamin laki-laki dan berusia 17-23 tahun. Sedangkan kriteria ekslusi pada penelitian ini adalah responden yang memiliki gangguan kesehatan bermakna yang telah didiagnosis oleh dokter yang menyebabkan responden mengalami kesulitan tidur, mengkonsumsi obat-obatan yang dapat menyebabkan mudah tidur dan sulit tidur serta mengkonsumsi alkohol atau kafein dengan jumlah $400 \mathrm{mg}$ per hari atau 3-4 cangkir per hari 
dalam kurun waktu 1 bulan sebelum pengambilan data.

Instrumen yang digunakan pada penelitian ini berupa kuesioner Pittsburgh Sleep Quality Index (PSQI) yang telah tervalidasi dan diterjemahkan kedalam bahasa Indonesia. ${ }^{14}$ Kuesioner ini tepat digunakan untuk mengetahui kualitas tidur baik dan buruk. Pertanyaan kuesioner PSQI terdiri dari 7 komponen yaitu kualitas tidur secara subyektif, latensi tidur, durasi tidur, efisiensi tidur, gangguan tidur, penggunaan obat tidur, dan disfungsi siang hari yang dinilai dalam kurun waktu 1 bulan terakhir. Kualitas tidur diukur dengan menjumlahkan 7 skor komponen kualitas tidur dengan rumus yang dibakukan.

Komponen pertama, kualitas tidur subyektif adalah kualitas tidur yang dirasakan oleh responden secara subyektif apakah tidurnya cukup nyenyak atau tidak. Pertanyaan kualitas tidur subyektif ini terdapat pada pertanyaan nomor 9 dengan jawaban yang bernilai 0 (sangat baik), 1 (baik), 2 (buruk) dan 3 (sangat buruk) Komponen kedua, latensi tidur adalah waktu yang dibutuhkan seseorang untuk tertidur. Pertanyaan

Tabel 1 Karakteristik subjek penelitian

\begin{tabular}{ll}
\hline Karakteristik & N \\
\hline Usia (tahun), min-max & $17-22$
\end{tabular}

\section{Angkatan Fakultas Kedokteran}

Angkatan tahun pertama

$25(15,6)$

Angkatan tahun kedua

$41(25,6)$

Angkatan tahun ketiga

$46(28,8)$

Angkatan tahun keempat

$48(30,0)$

Waktu tidur dimalam hari (wib) , min-max

22.00-03.00

Waktu bangun tidur dipagi hari (wib), min-max

03.00-08.30

N (\%)

Komponen 1 : Kualitas tidur subyektif

Sangat baik

$110(68,8)$

Baik

$30(18,8)$

Buruk

Komponen 2 : Latensi tidur

Sangat Buruk

$59(36,9)$

Tidak pernah

$42(28,8)$

1 kali seminggu

2 kali seminggu

$33(20,5)$

Komponen 3 : Durasi tidur

$$
\begin{aligned}
& >7 \mathrm{jam} \\
& 6-7 \mathrm{jam} \\
& 5-6 \mathrm{jam} \\
& <5 \mathrm{jam}
\end{aligned}
$$

$139(86,8)$

Komponen 4 : Efisiensi tidur

$>85 \%$

$20(12,5)$

$75-84 \%$

$36(22,5)$

$65-74 \%$

$67(41,9)$

Komponen 5 : Gangguan tidur 


$\begin{array}{cc}1 \text { kali seminggu } & 134(83,8) \\ 2 \text { kali seminggu } & 9(5,6) \\ \geq 3 \text { kali seminggu } & 0(0,0)\end{array}$

Komponen 6 : Penggunaan medikasi

Tidak pernah

$158(98,8)$

1 kali seminggu

$1(0,6)$

2 kali seminggu

$1(0,6)$

$\geq 3$ kali seminggu

$0(0,0)$

Komponen 7 : Disfungsi pada siang hari

Tidak pernah

1 kali seminggu

2 kali seminggu

$\geq 3$ kali seminggu

$36(22,5)$

Kualitas Tidur

Kualitas tidur baik

Kualitas tidur buruk

$150(93,8)$ latensi tidur ini terdapat pada pertanyaan nomor 2 dan 5a dengan jawaban yang bernilai $0(\leq 15$ menit), 1 (16-30 menit), 2 (31-60 menit) dan 3 ( $>60$ menit). Komponen ketiga, durasi tidur adalah keseluruhan waktu tidur yang dimiliki individu. Pertanyaan durasi tidur ini terdapat pada pertanyaan nomor 4 dengan jawaban yang bernilai 0 ( $>7$ jam), 1 (6-7 jam), 2 (5-6 jam) dan $3(<5$ jam). Komponen keempat, efisiensi tidur didapatkan dari perhitungan berdasarkan jam tidur dan bangun tidur di bagi jam lama tidur pulas seseorang. Efisiensi tidur didefinisikan sebagai rasio lama tidur yang sebenarnya dengan lama tidur di atas tempat tidur. Hasil pertanyaan ini adalah Efisiensi tidur = (total jumlah jam tidur/ total waktu di tempat tidur) X 100\% . Jawaban yang bernilai 0 (> 85\%), 1 (75-84\%), 2 (65-74\%) dan $3(<65 \%)$. Komponen kelima, gangguan tidur adalah kelainan yang bisa menyebabkan masalah pada pola tidur, baik karena tidak bisa tertidur, sering terbangun pada malam hari, atau ketidakmampuan untuk kembali tidur setelah terbangun. Pertanyaan gangguan tidur ini menjawab pertanyaan nomor $5 b-5 j$. Jawaban bernilai 0 (tidak ada pada bulan lalu), 1 (kurang dari sekali dalam seminggu), 2 (sekali atau dua kali dalam seminggu) dan 3 (tiga kali atau lebih dalam seminggu). Komponen keenam, penggunaan medikasi untuk tidur dalam jangka panjang dapat mengganggu pola tidur dan memperburuk masalah insomnia. Pertanyaan penggunaan obat tidur ini menjawab pertanyaan nomor 6 . Jawaban bernilai 0 (tidak ada pada bulan lalu), 1 (kurang dari sekali dalam seminggu), 2 (sekali atau dua kali dalam seminggu) dan 3 (tiga kali atau lebih dalam seminggu). Komponen ketujuh, disfungsi pada siang hari adalah ketika mengantuk hingga tertidur ketika mengemudi, makan, atau terlibat dalam aktivitas. Pertanyaan disfungsi pada siang hari ini menjawab pertanyaan nomor 7 dan 8 . Jawaban bernilai 0 (tidak ada pada bulan lalu), 1 (kurang dari sekali dalam seminggu), 2 (sekali atau dua kali dalam seminggu) dan 3 (tiga kali atau lebih dalam seminggu).

Nilai setiap komponen pertanyaan dilakukan penjumlahan dan pengkategorian kualitas tidur baik dan kualitas tidur buruk. Kualitas tidur dinyatakan baik apabila skor akhir kurang dari sama dengan 5. Kualitas tidur dinyatakan buruk apabila skor akhir lebih dari sama dengan 5. Serta diberikan pertanyaan tambahan pada kuesioner berupa pertanyaan karakteristik responden. Data yang didapat kemudian dianalisis perbandingannya menggunakan uji Chi-square. Hubungan dianggap bermakna apabila diperoleh nilai $\mathrm{p}<0,05$.

Penelitian ini telah mendapatkan izin dari Fakultas Kedokteran Universitas Padjadjaran, Jatinangor serta pernyataan kelayakan etik dari Komite Etik Penelitian Kesehatan Universitas Padjadjaran, Bandung, dengan nomor 596/UN6. C1.3.2/KEPK/PN/2016.

\section{Hasil}

Total populasi dalam penelitian ini sejumlah 160 responden yang dikelompokkan menjadi 80 responden yang menggunakan cahaya lampu saat tidur dan 80 responden yang tidak menggunakan 
Tabel 2 Perbandingan kualitas tidur Mahasiswa Fakultas Kedokteran Universitas Padjadjaran yang menggunakan dan tidak menggunakan lampu saat tidur

\begin{tabular}{|c|c|c|c|c|c|c|c|}
\hline \multirow{3}{*}{ Karakteristik } & \multicolumn{4}{|c|}{ Kualitas tidur } & \multirow[t]{3}{*}{$\mathbf{N}$} & \multirow[t]{3}{*}{$\%$} & \multirow[t]{3}{*}{ P value } \\
\hline & \multicolumn{2}{|c|}{ Baik } & \multicolumn{2}{|c|}{ Buruk } & & & \\
\hline & $\mathbf{F}$ & $\%$ & $\mathbf{F}$ & $\%$ & & & \\
\hline Penggunaan lampu & & & & & & & $0,191 *$ \\
\hline Ya & 7 & 8,75 & 73 & 91,25 & 80 & 100 & \\
\hline Tidak & 3 & 3,75 & 77 & 96,25 & 80 & 100 & \\
\hline Total & 10 & & 150 & & 160 & & \\
\hline
\end{tabular}

cahaya lampu saat tidur dan diperoleh data pada tabel 1.

Hasil yang ditunjukkan pada tabel 2 didapatkan dengan menggunakan analisa data chi-square untuk melihat perbandingan kualitas tidur mahasiswa Fakultas Kedokteran Universitas Padjadjaran yang menggunakan dan tidak menggunakan cahaya lampu saat tidur. Jika $<<0.05$ maka hasil penelitian dikatakan signifikan (H0 ditolak, H1 diterima).Pada tabel 2 menunjukkan nilai $\mathrm{p}$ value sebesar 0,191 atau $\mathrm{p}>0,05$, hal ini dapat disimpulkan bahwa $\mathrm{H} 0$ pada penelitian ini diterima atau tidak ada perbedaan kualitas tidur antara mahasiswa Fakultas Kedokteran Universitas Padjadjaran yang menggunakan dan tidak menggunakan cahaya lampu saat tidur.

\section{Pembahasan}

Berdasarkan penelitian yang telah dilakukan, hasil menunjukkan bahwa tidak ada perbedaan kualitas tidur antara mahasiswa Fakultas Kedokteran Universitas Padjadjaran yang menggunakan cahaya lampu dengan yang tidak menggunakan cahaya lampu saat tidur. Hasil ini tidak sesuai dengan penelitian yang dilakukan oleh Rusmiyati di Pontianak, Indonesia pada tahun 2015 menyatakan bahwa adanya pengaruh penggunaan cahaya lampu terhadap kualitas tidur pada remaja. Penelitian tersebut menunjukkan hasil yang bermakna. Didapatkan bahwa jumlah responden yang tidur menggunakan lampu sebanyak 24 atau 9,8\% dengan kualitas tidur baik dan 106 atau 43,1\% dengan kualitas tidur buruk. Sedangkan, responden yang tidur tidak menggunakan lampu sebanyak 63 atau 25,6\% responden dengan kualitas tidur baik dan 53 atau $21,5 \%$ dengan kualitas tidur buruk. Dari hasil penelitian yang dilakukan Rusmiyati tersebut menunjukkan bahwa responden yang tidak menggunakan lampu pada saat tidur membuat kualitas tidur akan semakin baik. ${ }^{14}$ Berdasarkan hasil penelitian Rusmiyati tersebut peneliti mengasumsikan bahwa adanya kualitas tidur yang lebih baik pada remaja dikarenakan tingkat pengawasan orang tua terhadap remaja masih tinggi karena masih tinggal bersama orang tua sedangkan mahasiswa sudah jauh dari pengawasan orang tua dan memiliki tuntutan untuk lebih mandiri dalam melakukan kegiatan hariannya. Namun, penelitian lain yang dilakukan oleh Aabid Ali di Pakistan tahun 2013 meneliti pola tidur mahasiswa kedokteran berdasarkan waktu tidur dan bangunnya mahasiswa yang dihitung menjadi durasi tidur. Hasil menunjukkan bahwa durasi tidur mahasiswa kedokteran tersebut termasuk durasi tidur yang kurang dari 6 jam. Hal ini dipaparkan oleh peneliti dari Pakistan bahwa mahasiswa kedokteran merupakan mahasiswa yang memiliki risiko tinggi terpapar stres selama tahun akademik yang dapat menyebabkan masalah psikologis yang mengakibatkan gangguan tidur. ${ }^{12}$ Mahasiswa kedokteran memiliki hari dan waktu malam lebih berat karena adanya tuntutan untuk menyelesaikan tugas presentasi, seminar, ujian mingguan dan bulanan serta aktivitas lain diluar perkuliahan seperti keorganisasian yang harus dilakukan dalam waktu terbatas. Hal ini yang menyebabkan mahasiswa kedokteran mengalami masalah tidur seperti kurang tidur dan rasa kantuk yang berlebihan pada siang hari. Sebagian besar mahasiswa berada dalam usia $15-24$ tahun yang termasuk kategori remaja menengah dan remaja tua yang masih berhadapan dengan fisiologis remaja seperti proses biologis yaitu fase tidur lambat. ${ }^{12}$

Menurut National Sleep Foundation, 59\% orang dewasa dengan usia 18-29 tahun menggambarkan diri mereka sebagai burung hantu pada malam hari. ${ }^{15}$ Sehingga pada usia tersebut, seseorang lebih memilih untuk terjaga lebih lama di malam hari untuk mengerjakan tugas dan memilih untuk menghabiskan waktu istirahat lebih lama pada hari libur seperti hari Sabtu dan Minggu. Hal ini didukung dengan penelitian yang dilakukan oleh Gaultney yang menunjukkan hasil bahwa banyak mahasiswa yang berisiko memiliki gangguan tidur dan kegagalan akademik. Berdasarkan penelitian 
Gaultney tersebut menyatakan adanya pengaruh dari pengetahuan seorang mahasiswa mengenai sleep hygiene yang benar salah satunya adalah lingkungan saat tidur, kebiasaan tidur pada siang hari, waktu tidur yang tidak teratur atau stimulasi yang berlebihan menjelang tidur. ${ }^{15}$ Selain hal tersebut, menurut National Sleep Foundation menyatakan penyebab seseorang sulit tidur yaitu masalah non medis yang dapat menyebabkan terjadinya kesulitan tidur yang berdampak pada kualitas tidur yaitu faktor emosi seperti kecemasan, stress hidup dan pikiran yang mengganggu menjelang tidur seperti yang telah dijabarkan diatas. ${ }^{16}$ Durasi tidur yang pendek dapat memengaruhi kualitas tidur responden. Dalam kuesioner PSQI terdapat komponen durasi tidur. Hasil penelitian menunjukkan mayoritas durasi tidur responden hanya tidur selama kurang dari 5 jam pada malam hari dan hanya 6 orang responden yang tidur selama lebih dari 7 jam pada malam hari. Menurut Kementrian Kesehatan Republik Indonesia menyatakan bahwa usia dewasa muda hingga dewasa tua (18-40 tahun) membutuhkan waktu tidur 7-8 jam pada malam hari. Berdasarkan penelitian ini didapatkan jumlah responden yang lebih banyak tidur kurang dari 5 jam pada malam hari, sehingga hal ini sangat memengaruhi kualitas tidur mahasiwa baik yang menggunakan cahaya lampu maupun tidak menggunakan cahaya lampu saat tidur. ${ }^{17}$ Selain durasi tidur yang kurang, faktor lainnya adalah kebiasaan sebelum tidur seperti penggunaan media elektronik seperti komputer dan televisi yang dapat meningkatkan risiko kualitas tidur yang buruk pada mahasiswa, hal ini sesuai dengan penelitian yang dilakukan oleh Mesquita, dkk. Menurut Mesquita, dkk yang menyatakan bahwa penggunaan media elektonik dapat membuat seseorang lebih dekat dengan layar media elektronik tersebut dan lebih melibatkan faktor mental serta fisik dalam mengoperasikannya. Hal ini membuat tingkat kewaspadaan seseorang meningkat dan lebih mementingkan untuk menyelesaikan aktivitas dengan media elektroniknya dibandingkan mendahulukan tidur. ${ }^{18}$

Pada penelitian ini diasumsikan bahwa faktorfaktor diatas dapat menjadi faktor lain yang memengaruhi subjek penelitian ini. Sehingga pada hasil penelitian ditemukan bahwa ada atau tidaknya paparan cahaya lampu saat tidur tidak memberikan perbedaan kualitas tidur pada mahasiswa Fakultas Kedokteran atau tidak memberikan hasil yang bermakna. Penelitian ini menunjukkan mahasiswa yang menggunakan lampu sebanyak 7 orang atau $8,75 \%$ responden memiliki kualitas tidur baik dan 73 orang atau $91,75 \%$ responden memiliki kualitas tidur buruk.
Sedangkan mahasiswa yang tidak menggunakan cahaya lampu saat tidur sebanyak 3 orang atau $3,75 \%$ memiliki kualitas tidur baik dan 77 orang atau 96,25\% memiliki kualitas tidur buruk. Hal ini menunjukkan bahwa antara mahasiswa Fakultas Kedokteran yang menggunakan cahaya lampu dan tidak menggunakan cahaya lampu saat tidur memiliki mayoritas kualitas tidur yang buruk. Adapun keterbatasan pada penelitian ini adalah kuesioner yang digunakan kurang sensitif terhadap subjek penelitian yaitu mahasiswa Kedokteran. Saran yang dapat diberikan dari penelitian ini adalah sebaiknya adanya modifikasi terhadap kuesioner baik dari segi pertanyaan maupun dalam pengkategorian interpretasi hasil kuesioner dan untuk mahasiswa sendiri sebaiknya dilakukan upaya pencegahan serta promosi kesehatan berupa edukasi mengenai sleep-hygiene yang benar sehingga walaupun tuntutan dari kegiatan akademik yang banyak namun dapat diseimbangkan dengan menerapkan sleep-hygiene yang benar di kehidupan seharihari.

\section{Daftar Pustaka}

1. John E. Hall P. Behavioral and Motivational Mechanisms of the Brain-The Limbic System and the Hypothalamus. in: Guyton AC, editor. Textbook of Medical Physiology. 13 ed. The United States of America: Elsevier; 2016. p. 751-61.

2. Keijzer H, Smits MG, Duffy JF, Curfs LM. Why the dim light melatonin onset (DLMO) should be measured before treatment of patients with circadian rhythm sleep disorders. Sleep Med Rev. 2014;18(4):333-9.

3. Reichert CF, Maire M, Schmidt C, Cajochen C. Sleep-Wake Regulation and Its Impact on Working Memory Performance: The Role of Adenosine. Biology (Basel). 2016;5(1):1-25..

4. Hubbard J, Ruppert E, Gropp CM, Bourgin P. Non-circadian direct effects of light on sleep and alertness: lessons from transgenic mouse models. Sleep Med Rev. 2013;17(6):445-52.

5. Bronsard G, Bartolomei F. Rhythms, rhythmicity and aggression. J Physiol Paris. 2013;107(4):327-34.

6. Krystal AD, Edinger JD. Measuring sleep quality. Sleep Medicine. 2008;9:S10-S7.

7. Augner C. Associations of subjective sleep quality with depression score, anxiety, physical symptoms and sleep onset latency in students. Cent Eur J Public Health. 2011;19(2):115-7.

8. Cho JR, Joo EY, Kood DL, Hong SB. Let there be no light: the effect of bedside 
light on sleep quality and background electroencephalographic rhythms. Sleep Med Rev. 2013;14:1422-5.

9. Burgard SA, Ailshire JA, Hughes NM. Gender and Sleep Duration among Americans Adults, Ann Arbor, Michigan. in: Anspach $\mathrm{R}$, Barber J, Harding D dkk., editors. ISA Research Committee 28 Meeting 2008; 2008 Aug; Michigan: USA; 2010. page 1-37.

10. Akhlaghi A-AK, Ghalebandi MF. Sleep Quality and Its Correlation with General Health in Pre-university Students of Karaj, Iran. Iranian Journal of Psychiatry and Behavioral Sciences. 2009;3(1):44-9.

11. Regal, Amigo, Cebrian. Sleep and Women. Rev Neurol. 2009;49(7):376-82.

12. Ali A, Majeed MB, Saba K, Bodenarain A, Bukhari MH. Effects of different sleeping patterns on academic performance in medical school students. Natural Science. 2013;05(11):1193-8.

13. Teixeira L, Lowden A, Luz AA, Turte SL,
Moreno CR, Valente D, et al. Exposure to bright light during evening class hours increases alertness among working college students. Sleep Med. 2013;14(1):91-7.

14. Rista SR, Yuyun T, Abror I. Effect Of Lamp Light Use With Juvnile's Sleep Quality in Madrasah Aliyah Negeri 2 Pontianak. Portal garuda 2015;1(1):1-6.

15. Gaultney JF. The prevalence of sleep disorders in college students: impact on academic performance. J Am Coll Health. 2010;59(2):91-7.

16. Counseling and Psychological Services Florida Institute of Technology. Sleep and Colege Life. 2015: 1-2.

17. Kementrian Kesehatan Republik Indonesia. Kebutuhan Tidur sesuai Usia. 2015:1-2.

18. Mesquita G, Reimao R. Quality of sleep among university students: Effects of nighttime computer and television use. Arq Neuropsiquiatr. 2010;68(5):720-5. 